\title{
Implementation of agent based holonic control in discrete manufacturing
}

\author{
Jana, T.K. ${ }^{\text {a, }}{ }^{\text {, }}$, Saha, P. ${ }^{\text {, }}$ Sarkar, B. ${ }^{\text {, }}$, Saha, J. ${ }^{\text {c }}$ \\ ${ }^{a}$ Department of Mechanical Engineering, Haldia Institute of Technology, Haldia 721 657, India \\ ${ }^{\mathrm{b}}$ Business Unit - Assembly, Test \& Paint, Tata Cummins Ltd, Jamshedpur 831 004, India \\ 'Department of Production Engineering, Jadavpur University, Kolkata 700 032, India
}

\begin{abstract}
A B S T R A C T
The present paper is aimed at implementation of agent based holonic manufacturing control, a Distributed Problem Solving (DPS) approach that relies on the principle of dynamic team formation through negotiation and cooperation by a group of intelligent system entities. A holonic system comprising product holon, resource holon, and integrated process planning and scheduling holon is developed to execute a customer order where negotiation based task allocation and scheduling is accomplished by Contract Net Protocol (CNP). The bids submitted by the resources are evaluated by Simple Additive Weight (SAW) technique under Fuzzy Multi Criteria Decision Making (FMCDM) environment. The priority of the products is established by the critical ratios (CR) to form the basis of scheduling rule. The necessary message based communication is accomplished using eXtensible Markup Language (XML) having specific Document Type Definition (DTD). The control is implemented by Linux operating system with Java.
\end{abstract}

(C) 2013 PEI, University of Maribor. All rights reserved.

\section{ARTICLE INFO}

Keywords:

Holonic manufacturing system

Multi agent system

Holarchy

Contract net protocol

Document type definition

*Corresponding author:

tarun.jana2000@gmail.com

(Jana, T.K.)

Article history:

Received 9 May 2012

Revised 14 August 2013

Accepted 6 September 2013

\section{References}

[1] Bussmann, S. (1998). An agent oriented architecture for holonic manufacturing control, In: First Open Workshop IMS Europe, Lausanne, Switzerland, 1-11.

[2] Bussmann, S., McFarlane, D.C. (1999). Rationales for holonic manufacturing control, In: Proceedings of $2^{\text {nd }}$ International Workshop on Intelligent Manufacturing System, Leuven, Belgium, 1-8.

[3] McFarlane, D.C., Bussmann, S. (2000). Developments in holonic production planning and control, International Journal of Production Planning and Control, Vol. 11, No. 6, 522-536.

[4] Van Brussel, H., Bongaerts, L., Wyns, J., Valckenaers, P., Van Ginderachter, T. (1999). A Conceptual framework for holonic manufacturing: identification of manufacturing holons, Journal of Manufacturing Systems, Vol. 18, No. 1, 35-52.

[5] Huang, B., Gou, H., Liu, W., Li, Y., Xie, M. (2002). A framework for virtual enterprise control with the holonic manufacturing paradigm, Computers in Industry, Vol. 49, No. 3, 299-310, doi: 10.1016/S0166-3615(02)00098-2.

[6] Smith, R.G. (1980). The contract net protocol: high-level communication and control in a distributed problem solver, IEEE Transactions on Computer, Vol. C-29, No. 12, 1104-1113, doi: 10.1109/TC.1980.1675516.

[7] Koestler, A. (1967). The ghost in the machine, Arkana Books, London.

[8] Hsieh, F.-S., Chiang, C.Y. (2011). Collaborative composition of processes in holonic manufacturing systems, Computers in Industry, Vol. 62, No. 1, 51-64, doi: 10.1016/j.compind.2010.05.012.

[9] Leitão, P. (2009). Agent-based distributed manufacturing control: A state-of-the-art survey, Engineering Application of Artificial Intelligence, Vol. 22, No. 7, 979-991, doi: 10.1016/j.engappai.2008.09.005.

[10] Wooldrigde, M., Jennings, N.R. (1995). Intelligent agents: theory and practice, The Knowledge Engineering Review, Vol. 10, No. 2, 115-152.

[11] Van Brussel, H., Wyns, J., Valckenaers, P., Bongaerts, L., Peeters. P. (1998). Reference architecture for holonic manufacturing systems: PROSA, Computers in Industry, Vol. 37, No. 3, 255-276. 
[12] Babiceanu, R.F.; Chen, F.F. (2006). Development and applications of holonic manufacturing systems: a survey, Journal of Intelligent Manufacturing, Vol. 17, No. 1, 111-131.

[13] Cao, Y., Yang, Y., Wang, H., Yang, L. (2009). Intelligent job shop scheduling based on MAS and integrated routing Wasp algorithm and scheduling Wasp algorithm, Journal of Software, Vol. 4, No. 5, 487-494, doi: 10.4304/jsw. 4.5.487-494.

[14] Giret, A., Botti, V. (2004). Holons and agents, Journal of Intelligent Manufacturing, Vol. 15, 645-659.

[15] Shen, W., Wang, L., Hao, Q. (2006). Agent-based distributed manufacturing process planning and scheduling: a state-of-the-art survey, IEEE Transaction on Systems, Man, and Cybernetics - Part C: Applications and Reviews, Vol. 36, No. 4, 563-577, doi: 10.1109/TSMCC.2006.874022.

[16] Wang, L., Shen, W., Hao, Q. (2006). An overview of distributed process planning and its integration with scheduling, International Journal of Computer Applications in Technology, Vol. 26, No. 1-2, 3-14, doi: 10.1504/IJCAT. 2006.010076.

[17] Wong, T.N., Leung, C.W., Mak, K.L., Fung, R.Y.K. (2006). Dynamic shop floor scheduling in multi-agent manufacturing systems, Expert Systems with Applications, Vol. 31, No. 3, 486-494, doi: 10.1016/j.eswa.2005.09.073.

[18] Ouelhadj, D., Petrovic, S. (2009). A survey of dynamic scheduling in manufacturing systems, Journal of Scheduling, Vol. 12, No. 4, 417-431, doi: 10.1007/s10951-008-0090-8.

[19] Cai, N., Wang, L., Feng, H.-Y. (2009). GA-based adaptive setup planning toward process planning and scheduling integration, International Journal of Production Research, Vol. 47, No. 10, 2745-2766, doi: 10.1080/0020754070 1663516.

[20] Cardin, O., Castagna, P. (2009). Using online simulation in holonic manufacturing systems, Engineering Applications of Artificial Intelligence, Vol. 22, No. 7, 1025-1033, doi: 10.1016/j.engappai.2009.01.006.

[21] Lai, L. (2009). Agent-based holonic dynamic and optimal manufacturing system for distributed manufacturing, In: International Conference on Environmental Science and Information Application Technology, Wuhan, China, 485-488, doi: 10.1109/ESIAT.2009.390.

[22] Sudo, Y., Sakao, N., Matsuda, M. (2010). An agent behavior technique in an autonomous decentralized manufacturing system, Journal of Advanced Mechanical Design Systems and Manufacturing, Vol. 4, No. 3, 673-682, doi: 10.1299/jamdsm.4.673.

[23] Adam, E., Berger, T., Sallez, Y., Trentesaux, D. (2011). Role-based manufacturing control in a holonic multi-agent system, International Journal of Production Research, Vol. 49, No. 5, 1455-1468, doi: 10.1080/00207543.2010. 522086.

[24] Renna, P. (2011). Multi-agent based scheduling in manufacturing cells in a dynamic environment, International Journal of Production Research, Vol. 49, No. 5, 1285-1301, doi: 10.1080/00207543.2010.518736.

[25] Nejad, H.T.N., Sugimura, N., Iwamura, K. (2011). Agent-based dynamic integrated process planning and scheduling in flexible manufacturing systems, International Journal of Production Research, Vol. 49, No. 5, 1373-1389, doi: $10.1080 / 00207543.2010 .518741$.

[26] Leitão, P. (2011). A holonic disturbance management architecture for flexible manufacturing systems, International Journal of Production Research, Vol. 49, No. 5, 1269-1284, doi: 10.1080/00207543.2010.518735.

[27] Lim, M.K., Zhang, Z. (2012). A multi-agent system using iterative bidding mechanism to enhance manufacturing agility, Expert System with Applications, Vol. 39, No. 9, 8259-8273, doi: 10.1016/j.eswa.2012.01.160.

[28] Leitão, P., Barbosa, J., Trentesaux, D. (2012). Bio-inspired multi agent systems for reconfigurable manufacturing systems, Engineering Applications of Artificial Intelligence, Vol. 25, No. 5, 934-944, doi: 10.1016/j.engappai.2011. 09.025 . 